\title{
INTENSIFICATION OF "MOLA” (Amblypharyngodon mola) CULTURE IN HOMESTEAD PONDS
}

\author{
S.N. Mona ${ }^{1}$, S. Sultana ${ }^{*}$, K.K. Ahmed3, N. Khan4, K.A. Huq ${ }^{5}$ and P. Mojumder
}

Received 5 August 2019, Revised 24 November 2019, Accepted 24 December 2019, Published online 31 December 2019

\begin{abstract}
The research was carried out with small indigenous fish species (SIS) named mola (Amblypharyngadan mola) in monoculture system to intensify production in farmers' homestead ponds with 50\% household women involvement during June to December, 2016. Brood mola was stocked at the rate of 2,4 and $6 \mathrm{~m}^{-2}$ with three replications in each treatment. Supplementary feed ( $27.1 \%$ protein) consisted of commonly available agricultural by-products was provided daily at the rate of $2 \%$ of the total biomass along with natural feed as mola is planktivorous species. Seven different water quality parameters were measured fortnightly and found within cultivable range. Gross production of mola were obtained $520.59 \pm 23.4,599.06 \pm 258.87,1063.94 \pm 42.87 \mathrm{~kg} \mathrm{ha}^{-1}$ from $\mathrm{T} 1, \mathrm{~T} 2$ and $\mathrm{T} 3$, respectively after 4 months' culture period. The yield of $\mathrm{T} 3$ was significantly greater $(\mathrm{P}<0.05)$ than $\mathrm{T} 1$ and $\mathrm{T} 2$. The highest gross production was obtained in T3 where stocking density was 6 brood mola $\mathrm{m}^{-2}$.
\end{abstract}

Keywords: Amblypharyngodon mola, Homestead pond, Monoculture, Intensification.

${ }^{1}$ Fisheries and Marine Resource Technology Discipline, Khulna University, Khulna - 9208, Bangladesh.

${ }^{2}$ Assistant Professor, Fisheries and Marine Resource Technology Discipline, Khulna University, Khulna - 9208, Bangladesh.

${ }^{3}$ Research Associate, WorldFish, Bangladesh.

${ }^{4}$ Project Manager, WorldFish Bangladesh \& South Asia Office.

${ }^{5}$ Professor, Fisheries and Marine Resource Technology Discipline, Khulna University, Khulna - 9208, Bangladesh.

*Corresponding author’s email: shamimasultana87@gmail.com (S. Sultana)

Cite this article as: Mona, S.N., Sultana, S., Ahmed, K.K., Khan, N., Huq, K.A. and Mojumder, P. 2019. Intensification of "Mola" (Amblypharyngodon mola) culture in homestead ponds. Int. J. Agril. Res. Innov. Tech. 9(2): 23-29. DOI: 10.3329/ijarit.v9i2.45406.

\section{Introduction}

Bangladesh is a small dense populated country where protein demand is increasing with population inflation. As a developing country, fishes are the main sources of animal protein to most of the rural Bangladeshi's (DoF, 2012). Small indigenous species (SIS) are enrich with micronutrients like vitamins and minerals. Result of different research showed deficiency of vit-A is wide spread in Bangladesh particularly in women and children (Micronutrient Initiative/UNICEF, 2004). Small indigenous species like Amblypharyngodon mola, nationally known as Mola is important component in the diet of the rural people in Bangladesh (Roos et al., 2002), which is not only an important source of protein but also rich source of a range of other essential nutrients. Rahman (1989) mentioned that $A$. mola is widespread in the rivers, streams, beels, ponds and inundated fields throughout
Bangladesh. Usually brood mola is using in the present well adapted polyculture practice (Alim et al., 2004; Kunda et al., 2008; Wahab et al., 2003). To date, there is no information about monoculture and induced spawning of mola in commercial hatchery of Bangladesh. Polyculture of carp species, prawn with SIS in homestead ponds is highly successful and well adapted in Bangladesh (Kohinoor et al., 2007). Vast number of small seasonal ponds in Bangladesh are often owned by poor or marginal farmer are typically underutilized resource for fish production which are a natural habitat for Mola and potentially suitable for its culture (alone or in combination with other species) (Roos et al., 2002). Mola is culturally accepted and affordable food for rural poor but declining capture fisheries in Bangladesh have decreasing accessibility. Mola in home stead aquaculture is suitable for home 
consumption as frequent harvesting (weekly/ even daily) is possible since it reproduces in pond. Once stocked, planktivorous mola (Mondal and Kaviraj, 2013) can reproduce 2-3 times in a year within homestead ponds and the new offspring become adult just after 3 to 5 months. Therefore, frequent harvesting could be done over the production cycle allowing for home consumption as well as sell. So, mola culture can be compared to home gardening, which is promoted as a strategy to combat vitamin and mineral deficiency (Helen Keller International, 1994). Gupta (1990) reported that in Bangladesh, rural women engage in subsistent aquaculture, which has helped in improving the quality of their families' lives. Considering the above circumstances, the present study was designed to optimize the stocking density of mola in monoculture system and develop women friendly

Table 1. Experimental design of homestead pond. monoculture of "mola" in homestead ponds to increase nutritional and economic benefit for the rural poor.

\section{Materials and Methods}

\section{Study period and area}

The experiment was carried out for six months during June to December, 2016. The study was conducted in farmers' homestead ponds (about 81 to $162 \mathrm{~m}^{2}$ ) at Fultola, Batiaghata Upazila, Khulna.

\section{Experimental design}

Three different stocking densities of mola ( $A$. mola) was maintained as same treatment with three replications in homestead ponds for monoculture system (Table 1).

\begin{tabular}{|c|c|c|c|c|c|c|c|}
\hline $\begin{array}{l}\text { Fish } \\
\text { Type }\end{array}$ & Treatment & Replication & $\begin{array}{l}\text { Pond size } \\
\qquad\left(\mathrm{m}^{2}\right)\end{array}$ & $\begin{array}{l}\text { Depth } \\
(\mathrm{m})\end{array}$ & $\begin{array}{l}\text { Stocking density } \\
\text { (ind. Fish } \mathrm{m}^{-2} \text { ) }\end{array}$ & $\begin{array}{l}\text { No. of } \\
\text { fish } \\
\text { stocked }\end{array}$ & $\begin{array}{l}\text { Weight at } \\
\text { stocking } \\
(\mathrm{kg})\end{array}$ \\
\hline \multirow{9}{*}{$\begin{array}{c}\text { Brood } \\
\text { mola }\end{array}$} & \multirow{3}{*}{$\mathrm{T}-1$} & $\mathrm{R}_{1}$ & 154.23 & 1.25 & 2 & 310 & 1.00 \\
\hline & & $\mathrm{R}_{2}$ & 154.23 & 1.25 & 2 & 310 & 1.00 \\
\hline & & $\mathrm{R}_{3}$ & 152.23 & 1.25 & 2 & 305 & 1.00 \\
\hline & \multirow{3}{*}{$\mathrm{T}-2$} & $\mathrm{R}_{1}$ & 110.75 & 1.25 & 4 & 444 & 1.50 \\
\hline & & $\mathrm{R}_{2}$ & 110.75 & 1.25 & 4 & 444 & 1.50 \\
\hline & & $\mathrm{R}_{3}$ & 92.17 & 1.40 & 4 & 370 & 1.25 \\
\hline & \multirow{3}{*}{$\mathrm{T}-3$} & $\mathrm{R}_{1}$ & 89.71 & 1.50 & 6 & 540 & 1.75 \\
\hline & & $\mathrm{R}_{2}$ & 73.87 & 1.50 & 6 & 444 & 1.50 \\
\hline & & $\mathrm{R}_{3}$ & 65.11 & 1.25 & 6 & 390 & 1.25 \\
\hline
\end{tabular}

\section{Pre stocking management}

Firstly, nine different farmers' ponds were selected and $50 \%$ female farmer's was also involved for the experiment. Maximum ponds were well exposed to sunlight and free from aquatic vegetation. The area of pond was ranged between 80 to $160 \mathrm{~m}^{2}$ at a water depth maintained between 1.2 to $1.5 \mathrm{~m}$ during the experimental period. Pond preparation was conducted before 10 days of stocking. Secondly, at the beginning, ponds were renovated and cleaned of aquatic vegetation. All unwanted fishes and other aquatic organisms were eradicated by repeated netting and by applying rotenone at the rate of $25 \mathrm{~kg} \mathrm{ha}^{-1} \mathrm{~m}^{-1}$. Pond dikes were repaired using the excavated bottom soils. The weeds of embankment were also cleaned manually. Surroundings of all ponds were fenced by $1 \mathrm{~m}$ high nylon net to prevent the entry of fishes, snakes and other predators. Then ponds were treated properly with lime at the rate of 250 $\mathrm{kg} \mathrm{ha}^{-1}$ after 3 days. Finally, after 4 or 5 days of liming, initial fertilization was done with urea, TSP and organic fertilizer at the rate of $50 \mathrm{~kg}, 25$ $\mathrm{kg}$ and $250 \mathrm{~kg} \mathrm{ha}^{-1}$, respectively. In addition, the mixture of molasses (30 kg ha-1) and yeast (400 g $\mathrm{ha}^{-1}$ ) was spread to the ponds to increase primary productivity after 24 hours' fermentation.

\section{Stocking management}

Brood mola were collected from the homestead pond of local farmers of Batiaghata Upazila, Khulna in August 2016. Ponds were stocked with fishes about four days after fertilization. Transportation was done in the early morning in oxygenated polybag. Before stocking, brood mola were acclimatized. After that, three treatments $\mathrm{T} 1, \mathrm{~T}_{2}$ and $\mathrm{T} 32$ were stocked with mola at the density of 2, 4 and 6 individual $\mathrm{m}^{-2}$. During stocking, the average ratio of male and female mola was 1:1.65. Initial length and weight of brood mola were measured before releasing into the pond. The mean initial weight of mola was $3.30 \pm 0.03 \mathrm{~g}, 3.45 \pm 0.06 \mathrm{~g}$ and $3.31 \pm 0.04 \mathrm{~g}$ in treatment $\mathrm{T} 1, \mathrm{~T} 2$ and $\mathrm{T}_{3}$, respectively.

\section{Post stocking management}

Proper post stocking management is needed for better production of culture species. Water quality measurement and sample collection were 
made between 07:00 - 10:00 am on each sampling day. Throughout the experimental period, the water quality parameters such as temperature $\left({ }^{\circ} \mathrm{C}\right)$; transparency $(\mathrm{cm})$; dissolved oxygen $\left(\mathrm{mg} \mathrm{L}^{-1}\right) ; \mathrm{pH}$, alkalinity $\left(\mathrm{mg} \mathrm{L}^{-1}\right)$ ammonia-nitrogen (mg L-1); Nitrate-nitrogen (mg $\mathrm{L}^{-1}$ ) were recorded fortnightly. Lime was applied fortnightly at the rate of $60 \mathrm{~kg} / 10^{4} \mathrm{~m}^{2}$ to keep the water clean and reducing the probability of disease outbreak. Besides that, Urea $\left(20 \mathrm{~kg} / 1 \mathrm{O}^{4}\right.$ $\left.\mathrm{m}^{2}\right)$ and TSP $\left(10 \mathrm{~kg} / 10^{4} \mathrm{~m}^{2}\right)$ were applied weekly and fermented mixture of molasses $\left(30 \mathrm{~kg} / 10^{4}\right.$ $\mathrm{m}^{2}$ ) and yeast ( $\left.400 \mathrm{~g} / 1 \mathrm{O}^{4} \mathrm{~m}^{2}\right)$ applied fortnightly in the pond for increasing natural food. Moreover, regular supplementary feed was applied for rapid growth and higher yields of fish. As the experiment was conducted, fish were fed daily at the rate of $2-3 \%$ body weight throughout the experiment. Half of the required food was applied in the morning at 7-8 am and the rest half in the evening at 5-6 pm.

Table 2. Supplementary feed ingredients and protein percentage.

\begin{tabular}{|l|c|c|c|}
\hline \begin{tabular}{|l|} 
Feed ingredients \\
Rice bran
\end{tabular} & $\begin{array}{c}\text { Amount of } \\
\text { ingredients (\%) }\end{array}$ & $\begin{array}{c}\text { Amount of protein in the } \\
\text { ingredients (\%) }\end{array}$ & $\begin{array}{c}\text { Amount of protein in the } \\
\text { feed (\%) }\end{array}$ \\
\hline Wheat bran & 30 & 12 & 3.6 \\
\hline Soyabean meal & 20 & 14 & 2.8 \\
\hline Mustard oilcake & 20 & 45 & 9.0 \\
\hline Fishmeal & 15 & 34 & 5.1 \\
\hline Wheat flour & 10 & 60 & 6.0 \\
\hline Total & 5 & 12 & 0.6 \\
\hline
\end{tabular}

Fish sampling was conducted at fortnightly intervals to know biomass and growth. To catch all size of mola fish a fine meshed seine net was made for sampling. To count the size distribution of mola, $100 \mathrm{~g}$ fishes was randomly taken as representative from the total sampled fish. Size distribution of mola was divided into larvae, $<1$, $1-2,2-3$ and $>3 \mathrm{~g}$ of weight.

\section{Harvesting}

After maintaining four months' culture period, fish was harvested in December, 2016. The fishes were caught by fine meshed seine net. The harvested fishes were counted and their lengths and weights were measured.

\section{Statistical analysis}

The data collected during experiment were recorded. For statistical analysis of data, a oneway ANOVA (Analysis of Variance) were done by using the Microsoft Excel 2013. Significance was assigned at the $5 \%$ level. Means were given with \pm standard error (SE).

\section{Results and Discussion}

\section{Water Quality Parameters}

Water quality parameters were analyzed to observe any appreciable changes that might have occurred in response to different treatments. Various physical, chemical and biological parameters of pond water were determined under treatment $\mathrm{T} 1, \mathrm{~T} 2$ and $\mathrm{T} 3$.

Table 3. Mean $( \pm \mathrm{SD})$ values and ranges of water quality parameters.

\begin{tabular}{|c|c|c|c|c|}
\hline Parameters & Treatment-1 & Treatment-2 & Treatment-3 & $\begin{array}{c}\text { ANOVA } \\
\text { Significance }\end{array}$ \\
\hline Temperature $\left({ }^{\circ} \mathrm{C}\right)$ & $\begin{array}{l}28.53 \pm 1.54 \\
(26.3-30.9)\end{array}$ & $\begin{array}{l}28.22 \pm 1.43 \\
(26.0-30.5)\end{array}$ & $\begin{array}{l}28.63 \pm 1.37 \\
(26.5-30.5)\end{array}$ & NS \\
\hline Alkalinity (mg L L-1) & $\begin{array}{c}109.88 \pm 16.88 \\
(72-134)\end{array}$ & $\begin{array}{c}108.63 \pm 13.62 \\
(84-133)\end{array}$ & $\begin{array}{c}108.63 \pm 13.54 \\
(80-130)\end{array}$ & NS \\
\hline Transparency (cm) & $\begin{array}{c}25.80 \pm 3 \cdot 30 \\
(20-32)\end{array}$ & $\begin{array}{c}26.20 \pm 3.40 \\
(20-32)\end{array}$ & $\begin{array}{c}25 \cdot 50 \pm 3.20 \\
(19-31)\end{array}$ & NS \\
\hline $\mathrm{DO}\left(\mathrm{mg} \mathrm{L}^{-1}\right)$ & $\begin{array}{c}3.26 \pm 1.18 \\
(2.0-5.3)\end{array}$ & $\begin{array}{c}3.33 \pm 1.33 \\
(2.0-5 \cdot 9)\end{array}$ & $\begin{array}{c}3.34 \pm 1.09 \\
(2-5)\end{array}$ & NS \\
\hline $\mathrm{pH}$ & $\begin{array}{c}7.53 \pm 0.12 \\
(7 \cdot 3-7.8)\end{array}$ & $\begin{array}{c}7.45 \pm 0.22 \\
(7.3-8.3)\end{array}$ & $\begin{array}{c}7.50 \pm 0.88 \\
(7.4-7.7)\end{array}$ & NS \\
\hline $\mathrm{NH}_{3}-\mathrm{N}\left(\mathrm{mg} \mathrm{L}^{-1}\right)$ & $\begin{array}{c}0.440 \pm 0.073 \\
(0.31-0.59)\end{array}$ & $\begin{array}{c}0.480 \pm 0.073 \\
(0.32-0.60)\end{array}$ & $\begin{array}{c}0.420 \pm 0.068 \\
(0.35-0.62)\end{array}$ & NS \\
\hline $\mathrm{NO}_{3}-\mathrm{N}\left(\mathrm{mg} \mathrm{L}^{-1}\right)$ & $\begin{array}{c}0.021 \pm 0.009 \\
(0.007-0.037)\end{array}$ & $\begin{array}{c}0.018 \pm 0.007 \\
(0.009-0.033)\end{array}$ & $\begin{array}{c}0.019 \pm 0.008 \\
(0.008-0.034)\end{array}$ & NS \\
\hline
\end{tabular}

${ }^{*} N S=$ Not significantly different at $5 \%$ level of significance $(P>0.05)$ 
All parameters were more or less within the acceptable range for fish culture. No significant difference $(\mathrm{P}>0.05)$ was observed among the different treatments in one-way ANOVA test. Water quality parameters in different treatments have been presented in Table 3. Many researchers concluded more or less similar findings as the recent research (Mairs, 1966; Boyd, 1982; Wahab et al., 1995; Huq et al., 2004;

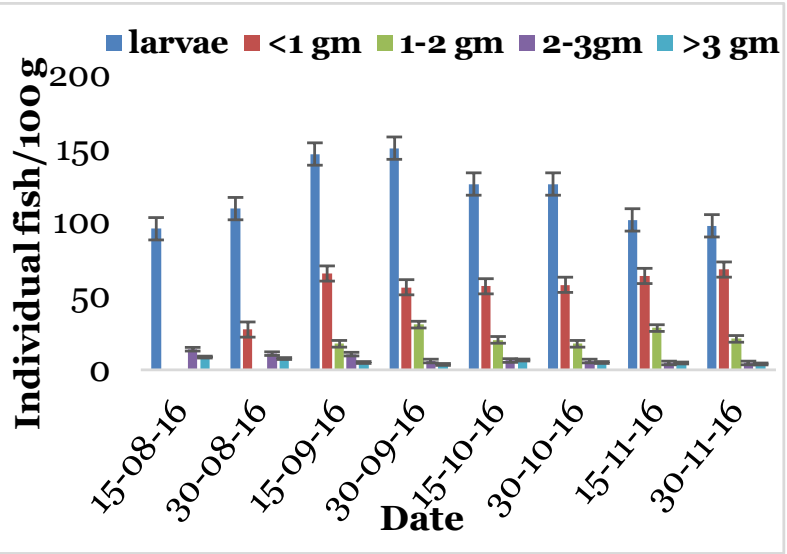

A. Treatment-1
Alim, 2005; Rahman, 2005; Kunda et al., 2008; Hoque et al., 2014).

\section{Size distribution, growth and biomass of mola}

Size distributions of mola during the experimental period in homestead ponds are shown in Fig. 1.

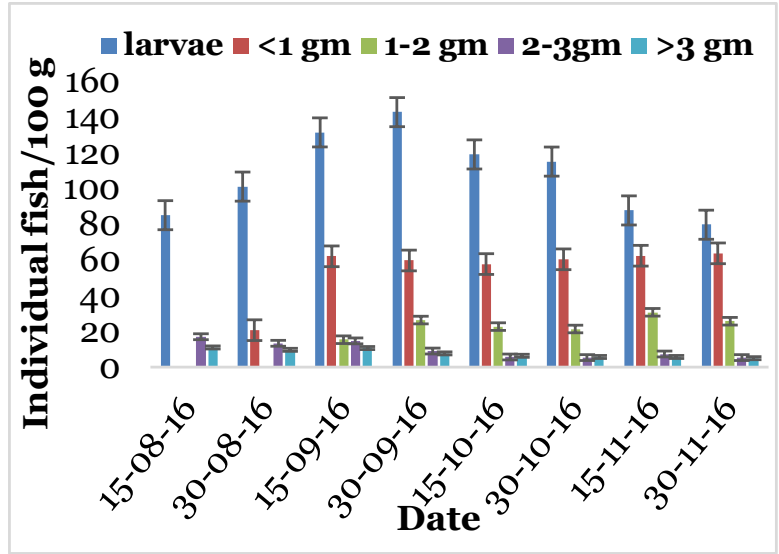

B. Treatment-2

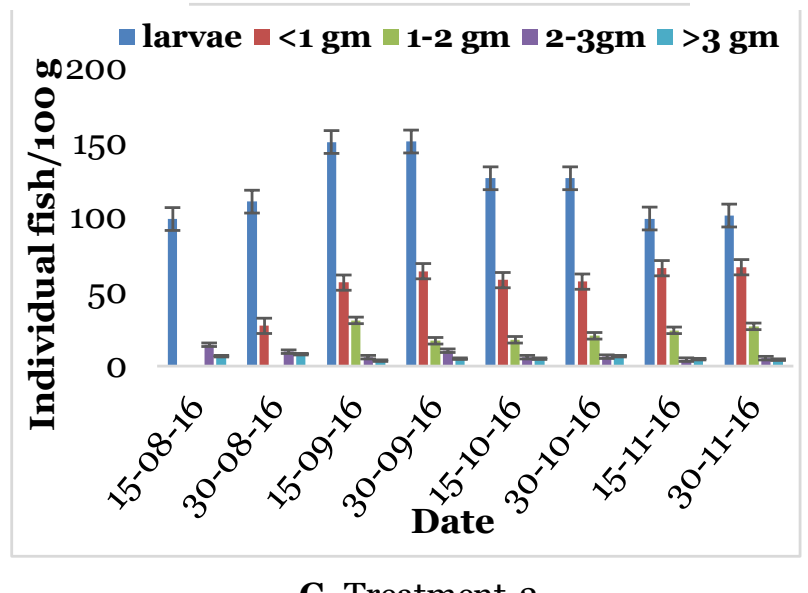

C. Treatment-3

Fig. 1. Size distribution of $100 \mathrm{~g}$ mola among three treatments.

Brood mola was stocked in early August, therefore larvae and small mola of sized $<1 \mathrm{~g}$ and 1-2 $g$ were absent in middle of August while in last August mola larvae $<1 \mathrm{~g}$ was seen in the net during sampling in all replications of three treatments. Therefore, in the next successive months, all size range mola were found during the sampling. The mean number of fry mola \pm SD was increased from $95.67 \pm 7.10$ to $150.33 \pm 1.53$ individual/100 g mola during middle of August to till last September in $\mathrm{T} 1$, then a slow downward trend showed in the distribution pattern of mola larvae end up with $97.67 \pm 1.53$ individual/100 $\mathrm{g}$ mola in the last November in T1. Same pattern of distribution mola larvae were also observed in T2 and $\mathrm{T}_{3}$. But in case of mola larger than $3 \mathrm{~g}$, the mean number \pm SD was increased in last August and September, but decreased in the following months in T1 (Fig. 1). Similar pattern of same sized mola distribution were also observed in $\mathrm{T} 3$ with pick in last August and October. In case of $\mathrm{T} 2$, trend was not similar to that of other two treatments as may be seen in Fig. 1. The mean number $\pm \mathrm{SD}$ of mola larger than $3 \mathrm{~g}$ was found to increase in middle August and September but then gradually deceased in the following months. The total biomass of mola in $\mathrm{T} 3$ was found to vary significantly higher than those of $\mathrm{T} 1$ and $\mathrm{T} 2$ $(\mathrm{P}<0.05)$. The biomass of mola showed an increasing trend with time. The biomass was found higher in all sampling in $\mathrm{T}_{3}$ where brood mola stocking density was $6 \mathrm{~m}^{-2}$. The biomass of mola in T3 was $253.67 \mathrm{~kg} \mathrm{haul}^{-1} \mathrm{ha}^{-1}$ higher than that of $\mathrm{T} 1$ and T2. (Fig. 2). 


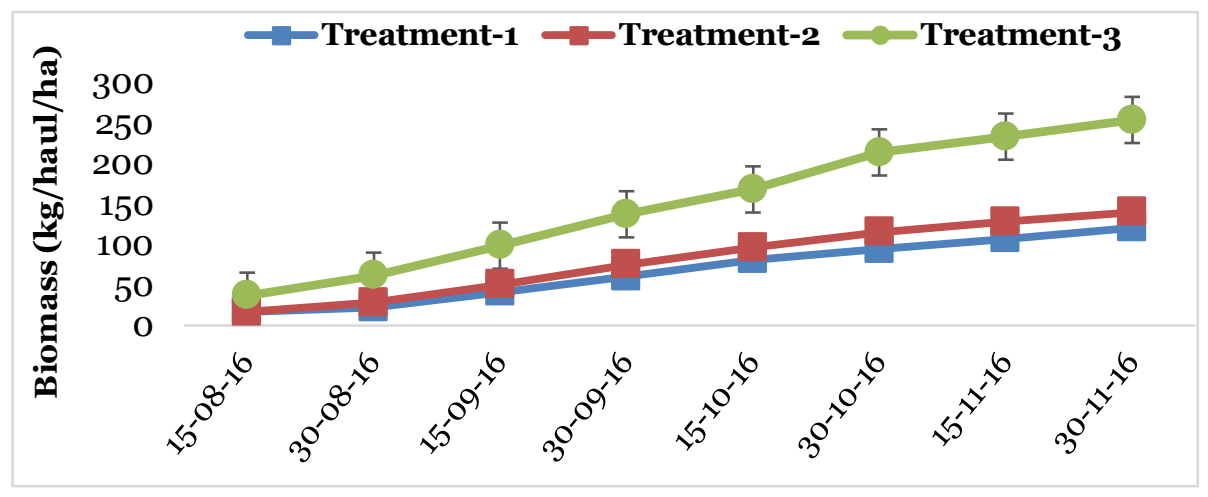

Fig. 2. Average biomass $\left(\mathrm{kg} / \mathrm{haul} / 1 \mathrm{O}^{4} \mathrm{~m}^{2}\right)$ of mola among three treatments.

Mamun et al. (2004) have reported high feeding intensity in $A$. mola but have not correlated it with breeding periodicity. Piska et al. (1991) have reported that feeding intensity is low during the spawning season and high during pre-spawning and post-spawning period of $A$. mola; this observation has later been supported by Suresh et al. (2007), Gupta and Banerjee (2013) and Mondal and Kaviraj (2013). Piska and Waghray (1986) also have reported high incidence of empty guts coincided with the spawning season of A. mola. Most of the homestead ponds in the present research were situated in the shady area near the farmer's residence. Phytoplankton growth might be hindered due to absence of adequate light despite of enough application of fertilizers, which could be a major reason of unexpected low production.

\section{Production statistics of mola}

The production at harvest of each treatment of $\mathrm{T} 1, \mathrm{~T} 2$ and $\mathrm{T} 3$ were higher than their stock. At harvest, the total production of $\mathrm{T}_{3}$ was significantly higher $(\mathrm{P}<0.05)$ than those of $\mathrm{T} 1$ and $\mathrm{T} 2$. But the total production of $\mathrm{T} 2$ and $\mathrm{T} 3$ were also showed significant difference $(\mathrm{P}>0.05)$. The total production of $\mathrm{T} 1, \mathrm{~T} 2$ and $\mathrm{T}_{3}$ harvested were $520.59,599.06$ and $1063.94 \mathrm{~kg} / 10^{4} \mathrm{~m}^{2}$, respectively. The stocking and production statistics of mola during the experimental period in homestead ponds represented in Table 4.

Table 4. Details of stocking and production statistics of mola under three different treatments.

\begin{tabular}{|c|c|c|c|c|c|c|c|}
\hline \multirow{2}{*}{ Treatment } & \multirow{2}{*}{$\begin{array}{l}\text { Avg. pond } \\
\text { size }\left(\mathrm{m}^{2}\right)\end{array}$} & \multicolumn{3}{|c|}{ Stocking } & \multicolumn{3}{|c|}{ Harvesting } \\
\hline & & $\begin{array}{c}\text { Stocking } \\
\text { density } \\
\text { (individual/ } \\
\mathrm{m}^{2} \text { ) }\end{array}$ & $\begin{array}{l}\text { Avg. } \\
\text { initial ind. } \\
\text { brood wt. } \\
\text { (g) }\end{array}$ & $\begin{array}{c}\text { Avg. Mola } \\
\text { Stock } \\
(\mathrm{kg} / \text { pond })\end{array}$ & $\begin{array}{l}\text { Avg. final } \\
\text { ind. wt. } \\
\text { (g) }\end{array}$ & $\begin{array}{c}\text { Avg. } \\
\text { Production } \\
\text { (kg/pond) }\end{array}$ & $\begin{array}{c}\text { Total } \\
\text { Production } \\
\left(\mathrm{kg} / 10^{4} \mathrm{~m}^{2}\right)\end{array}$ \\
\hline $\mathrm{T}-1$ & $153.56 \pm 1.15$ & 2 & $3.30 \pm 0.03$ & $1.00 \pm 0.00$ & $1.35 \pm 0.03$ & $7.99 \pm 0.30$ & $520.59 \pm 23.40^{a}$ \\
\hline $\mathrm{T}-2$ & $104.56 \pm 10.73$ & 4 & $3.45 \pm 0.06$ & $1.42 \pm 0.14$ & $1.66 \pm 0.06$ & $6.10 \pm 1.91$ & $599.06 \pm 258.87^{\mathrm{a}}$ \\
\hline $\mathrm{T}-3$ & $76.23 \pm 12.47$ & 6 & $3.31 \pm 0.04$ & $1.5 \pm 0.25$ & $1.27 \pm 0.04$ & $8.11 \pm 1.31$ & $1063.94 \pm 42.87^{b}$ \\
\hline
\end{tabular}

*Figures in the same row having the same superscript are not significantly different $(P>0.05)$.

The numbers of harvested mola per sq.m was higher in $\mathrm{T}_{3}$ than other two treatments and showed significant difference $(\mathrm{P}>0.05)$ than other two treatments. The yield of mola over a period of four months from $\mathrm{T} 1, \mathrm{~T} 2$ and $\mathrm{T} 33$ were $520.59,599.06$ and $1063.94 \mathrm{~kg} \mathrm{ha}^{-1}$, respectively. The total production of mola in $\mathrm{T}_{3}$ was found to vary significantly higher than those of $\mathrm{T} 1$ and $\mathrm{T} 2$ $(\mathrm{P}<0.05)$. The highest percentage of production was obtained from $\mathrm{T}_{3}$, which was $49 \%$ higher than that of T1 and T2.

Some of the notable works are Asadujjaman et al. (2013), Ameen et al. (1984), Akhteruzzaman et al. (1990) and Hossain et al. (1997). The total productions of mola varied among three treatments, which indicated that there was an effect of stocking density on the growth performance and production of mola.

In the present experiment, the mean final production of mola in three different treatments of homestead ponds were 520.59 \pm 23.40 , $599.06 \pm 258.87$ and $1063.94 \pm 42.87 \mathrm{~kg} \mathrm{ha}^{-1}$, respectively. The mean final weights of mola in $\mathrm{T} 1, \mathrm{~T} 2$ and $\mathrm{T} 3$ of homestead ponds were $1.35 \pm 0.03,1.66 \pm 0.06,1.27 \pm 0.04 \mathrm{~g}$, respectively, probably due to huge number of small mola or larvae in $\mathrm{T}_{3}$ than others. Besides that, final harvesting was conducted in last winter, season could be another factor of lower production than expected one. Mustafa (1991) reported the mean weight of mola and punti were 3.03 and $7.65 \mathrm{~g}$, respectively in his monoculture experiment. On the other hand, Kohinoor et al. (1998) found the 
mean weight of mola in polyculture system was 0.74 g, whereas, Hasan (1998) in his polyculture experiment with small fish observed the mean weights of mola, punti and chela as 1.10, 3.69 and $1.80 \mathrm{~g}$, respectively. In the present experiment, mean production of mola was $520.59 \pm 23.40$, $599.06 \pm 258.87$ and $1063.94 \pm 42.87 \mathrm{~kg} \mathrm{ha}^{-1}$ per 4 months which were much higher than the findings of Asadujjaman et al. (2013) as well as Mustafa (1991) who reported to achieve an estimated production of $1,592 \mathrm{~kg} \mathrm{ha}^{-1} \mathrm{yr}^{-1}$ from monoculture of mola. Ameen et al. (1984) obtained a production of 1.75 tons' $^{\text {ha }} \mathrm{a}^{-1}$ of mola (A. mola) in mono culture. Rahmatullah et al. (1998) reported to obtain a net yield of chapila to be $92.13 \mathrm{~kg} \mathrm{ha}^{-1}$ and mola to be $57.88 \mathrm{~kg} \mathrm{ha}^{-1}$ per 3 months. The fish production as obtained in the present experiment was higher than to all the above mentioned findings. Production of T2 of the present research could be higher if two ponds (T2R1 and T2R2) were not situated in fully shady area. Probably this is the main reason behind lower production in T2 in Botiaghata homestead ponds. During harvesting the major portion of mola was larvae and small fish. If all the small fishes get opportunity to become marketable size (2-5 g), then production could be raised 3-4 folds than the present production. Brood mola was stocked in early August, which missed the early spawning season of mola. Mola started spawning in early monsoon when heavy rain falls occur. If brood mola could be stocked in early monsoon (May to June), production might become much higher.

\section{Cost-benefit analysis}

The total production costs, income and benefit are presented in the following Table 5. Average income was found $1,81,965.83 \pm 7,3420.89$ BDT ha $^{-1}$. Average benefit was found $13,604.83 \pm 7,3420.89$ BDT ha-1. Very little amount of benefit was found in this monoculture system than other culture systems though there is a great opportunity for mola culture. This type of culture practice is only suitable for household consumption and nutritional benefit not for economic benefit.

Table 5. Fish production, gross income and benefit.

\begin{tabular}{|l|cc|}
\multicolumn{1}{c}{ Issue } & $\begin{array}{c}\text { Avg. Production } \\
\left(\mathrm{kg} / \mathrm{I0}^{4} \mathrm{~m}^{2} / 4 \text { months }\right)\end{array}$ & $\begin{array}{c}\text { Avg. Income } \\
(\mathrm{BDT} / 4 \mathrm{months})\end{array}$ \\
\hline Mola & $727.86 \pm 293.68$ & $\mathbf{1 , 8 1 , 9 6 5 . 8 3 \pm 7 , 3 4 2 0 . 8 9 / -}$ \\
\hline Avg. production cost & - & $\mathbf{1 , 6 8 , 3 6 1 / -}$ \\
\hline Avg. Benefit & - & $\mathbf{1 3 , 6 0 4 . 8 3 \pm 7 , 3 4 2 0 . 8 9 / -}$ \\
\hline
\end{tabular}

However, if we stocked fish in first spawning time, we will get twice or thrice production more than present production and we will be economically benefited through this culture system. Farmers can apply simple culture technique of mola with a little input over short period with both natural and minimum supplementary feed. Finally, the poor people may get a chance to consume them readily and sale in the market to earn additional money.

\section{Acknowledgement}

The authors take the privilege to acknowledge the "Federal Ministry for Economic Cooperation and Development, Germany" for financial support through WorldFish Bangladesh and Bangladesh Fisheries Research Forum (BFRF) for sincere supervision. The President of BFRF, Prof. Dr. Md. Jahangir Alam is acknowledged for their cooperation during this study. This work could not have been done without the hard work of the 9 farmers and their families who carried out the experiment in their ponds.

\section{References}

Akhteruzzaman, M., Kohinoor, A.H.M., Hussain, M.G. and Shah, M.S. 1990. A study on the semi-intensive culture of Puntius sarana (Ham.). Bangladesh J. Fish. 14(12): 69-72.
Alim, M.A. 2005. Developing A Fish Polyculture Technique for Farmers' Consumption and Cash Crop. Ph.D. Dissertation, Department of Fisheries Management, Bangladesh Agricultural University, Mymensingh. 153p.

Alim, M.A., Wahab, M.A. and Milstein, A. 2004. Effects of adding different proportions of the small fish punti (Puntius sophore) and Mola (Amblypharyngodon mola) to a polyculture of large carp. Aqua. Res. 35: 124-133.

Ameen, M., Islam, K.R., Ahmed, K. and Mustafa, G. 1984. Indigenous small fish culture in mini ponds. Bangladesh J. Zool. 12(1): 1-10.

Asadujjaman, M., Wahab, M.A., Fatema, M.K., Hossain, M.B. and Azam, A.K.M.S. 2013. Effects of Stocking Density on Growth Performance and Production of Mola, Amblypharyngodon mola. Sains Malays. 42(11): 1565-1569.

Boyd, C.E. 1982. Water quality management for pond fish culture. Elsevier Science Publication Company Amsterdam-OxfordNew York. 318p.

DoF, 2012. National Fish Week 2012 Compendium (in Bengali). Department of Fisheries, Ministry of Fisheries and Livestock, Dhaka, Bangladesh. 144p.

Gupta, M.V. 1990. Rural Women in Aquaculture Bangladesh. Naga, The ICLARM Quar. 13(3): 8 . 
Gupta, S. and Banerjee, S. 2013. Food and feeding habit of Amblypharyngodon mola (Hamilton Buchanan, 1822) in West Bengal, India. Int. J. Sci. Res. 2(5): 293-297.

Hasan, M.A. 1998. Development of carp polyculture techniques with small indigenous fish species mola Amblypharyngodon mola, chela Chela cachius, punti, Puntius sophore. M.S. Thesis, Department of Fisheries Management, BAU, Mymensingh. 71p.

Helen Keller International/Asian Vegetable Research Center. 1994. Home

Gardening in Bangladesh.

Keller International, Dhaka. 9p.

Hoque, M.M., Motin, M.A., Maya, M., Sarkar, M.R.U., Islam, M.R., Chowdhury, M.T.H. and Chowdhury, A.J.K. 2014. Water Quality and Plankton Composition of Amblypharyngodon mola Monoculture Fish Pond in Bangladesh. Int. J. Emerg. Trends Sci. Tech. 1(7): 1005-1014.

Hossain, M.A., Afsana, K., Shah, A.K.M.A. 1997. Nutritional value of some small indigenous fish species (SIS) of Bangladesh. Bangladesh J. Fish. Re. 3(1): 77-85.

Huq, K.A., Manir, S.M.I., Rahman, M.M. and Ferdous, K.S. 2004. Production performance of Macrobrachium osenbergii (De Man) in monoculture versus polyculture system. J. Bangladesh Agric. Univ. 2(1): 141-149.

Kohinoor, A.H.M., Islam, M.L., Wahab, M.A. and Thilsted, S.H. 1998. Effect of mola (Amblypharyngodon mola Ham.) on the growth and production of carps in polyculture. Bangladesh J. Fish. Res. 2(2): $119-126$.

Kohinoor, A.H.M., Sultana, S. and Hussain, M.G. 2007. Polyculture of carp with small indigenous fish, bata, Labeo bata (Ham.) at different stocking densities. Bangladesh $J$. Fish. Res. 11(1): 29-36.

Kunda, M., Azim, M.E., Wahab, M. A., Roos, N., Thilsted, S.H. and Dewan, S. 2008. The potential of mixed culture of fresh water prawn (Macrobrachium rosenbergii) and small indigenous mola (Amblypharyngodon mola) in rain-fed rotational rice -fish culture system in Bangladesh. Aqua. Res. 39: 506-517.

Mairs, D.F. 1966. A total alkalinity atlas for marine lake waters. Limnol. Oceanogr. 11: 68-72.

Mamun, A., Tareq, K.M.A. and Azadi, M.A. 2004. Food and feeding habits of Amblypharyngodon mola (Hamilton) from Kaptai reservoir, Bangladesh. Pakistan $J$. Biol. Sci. 7(4): 584-588.
Micronutrients Initiatives/UNICEF. 2004. Vitamin A and mineral deficiency: A global report. Ottawa, Canada. 9p.

Mondal, D.K. and Kaviraj, A. 2013. Feeding and reproductive biology of Amblypharyngodon mola (Cypriniformes: Cyprinidae) from two floodplain lakes of India. Int. J. Aqua. Biol. 1(3): 125-131.

Mustafa, G. 1991. Composite culture and biology of some indigenous fishes of Bangladesh. $\mathrm{PhD}$ Dissertation, Faculty of Biological Science, Dhaka University, Dhaka, Bangladesh. 299p.

Piska, R.S. and Waghray, S. 1986. Some aspects of reproductive biology of Amblypharyngodon mola (Hamilton). Geobios. 13(5): 204-207.

Piska, R.S., Swamy, B.R. and Devi, P.J. 1991. Food and feeding habits of fresh water cyprinid Amblypharyngodon mola (Ham.). Indian J. Fish. 38: 126-128.

Rahman, A.K.A. 1989. Freshwater Fishes of Bangladesh. Zoological Society of Bangladesh, Dhaka. 352p.

Rahman, S.M.S. 2005. Effect of stocking density of gift strain of nile tilapia (Orechromis niloticus) and freshwater prawn (Macrobrachium rosenbergii) in periphyton based production system. MS Thesis, Dept. of Fisheries Management, Bangladesh Agricultural University, Mymensingh. 84p.

Rahmatullah, S.M., Ahmed, S. and Hossain, M.A. 1998. Studies on the production of small fishes mola, Amblyphmyngodon mola and chapila, Gudusia chapra. Bangladesh $J$. Agril. Sci. 25(2): 267-271.

Roos, N., Thilsted, S.H. and Wahab, M.A. 2002. Culture of small indigenous fish species in seasonal ponds in Bangladesh: The potential for production and impact on food and nutrition security. In: Rural Aquaculture (eds. P Edwards, D C Little and H Demaine), CABI Publishing, UK. pp. 245-252.

Suresh, V.R., Biswas, B.K., Vinci, G.K., Mitra, K. and Mukherjee, A. 2007. Biology of Amblypharyngodon mola (Hamilton) from a floodplain wetland, West Bengal. Indian $J$. Fish. 54(2): 155-161.

Wahab, M.A., Ahmed, Z. F., Islam, M.A. and Rahmatullah, S.M. 1995. Effects of introduction of common carp, Cyprinus carpio (L.) on the pond ecology and growth of fish in polyculture. Aqua. Res. 26(9): 619-628.

Wahab, M.A., Alim, M. A. and Milstein, A. 2003. Effects of adding the small fish punti (Puntius sophore) and/or mola (Amblypharyngodon mola) to a polyculture of large carp. Aqua. Res. 34: 149-164. 